\title{
Filtration Drying of cotton
}

\author{
D.J Janabayev ${ }^{1}$, V.M. Atamanyuk ${ }^{2}$, A.E. Khussanov ${ }^{1}$, Z.Ya. Gnativ², B.M. Kaldybaeva ${ }^{1}$ \\ 1. Scientific Laboratory "Water Problems", M.Auezov South Kazakhstan State University, KAZAKHSTAN, \\ Shymkent, Taukekhan avenue, 5, E-mail: khusanov_1975@inbox.ru
}

2. Department of Chemical Endineering, Lviv Polytechnic National University, UKRAINE, Lviv,12 S.Bandera street, E-mail: atamanyuk@ukr.net.

Cotton is one of the most valuable raw materials for the production of industrial and food products. Therefore modernization of processing of cotton is extremely important for development of economy of Kazakhstan.According to the state program for Agricultural Development of the Republic of Kazakhstan, in 2017-2021 to 2021 the acreage of cotton in the South Kazakhstan region should increase by 100 thousand tons. Ha, yield - up to 30 cents/ha and production of cotton up to 300 thousand tons./year. Therefore, experimental and theoretical studies of cotton drying are of actual importance.

Keywords: fibrous materials, filtration drying, hydrodynamics, moisture, thermal agent

\section{Introduction}

The analysis of the sources of literature [1-3] makes it possible to conclude that there is no complex and systemic approach to the intensification of processes of cotton drying, taking into account the fact that it contains mainly bound moisture, it is a thermolabile material, and The drying process takes place in the second period.

It is known that filtration drying is one of the highly effective methods. The essence of filtration drying is the filtration of thermal agent through a stationary porous layer of wet material, which provides high coefficients of heat and mass. At this, the total waste of energy on the drying process consists of pressure losses in the stationary layer and heating of the heat agent (air) to the desired temperature.

\section{Result of research and discussion}

The experimental research on the filtration of thermal agent through the stationary layer of cotton in different bulk weight and different heights of a layer represented in the form of functional dependence $\Delta \mathrm{P}=f\left(v_{0}\right)$. Generalization of experimental data of the hydrodynamics of filtration of thermal agent through a stationary layer of cotton was conducted in the form of dimensionless complexes. $E u=f(R e, \Gamma)$, as well as the determined dependence of the hydraulic resistance coefficient of a layer as Reynolds number $\lambda=f(R e)$. The results obtained in dimensionless form provide the possibility to predict energy costs for the creation of pressure differential (in the same hydrodynamic conditions) while designing new drying equipment. Taking into account that the filtration drying has zonal character conducted experimental researches on heat exchange between thermal agent and dry and fibre cotton. The factors of heat transfer for dry fiber cotton determined from heat transfer equation, and wet from the equation of mass-giving. The results of experimental researches were presented as $\alpha=f(v)$, a generalization in the form of functional dependencies $N u=f(\operatorname{Re}, \operatorname{Pr})$ and $S h=f(R e, S c)$. Kinetics filtration Drying of fiber cotton was investigated at different heights of the stationary layer $(\mathrm{H}=60-160 \mathrm{~mm})$ and temperature of thermal agent $\mathrm{T}=318$, $333,353,373 \mathrm{~K}$, the speed of filtration of thermal agent was $1.0 ; 1.4 ; 1.8$ and $2.0 \mathrm{~m} / \mathrm{s}$. Results Represented in the form of dependence of changes in the in time, as well as changes in drying 
speed from moisture content. Based on the results of filtration drying, cotton determined the value of an effective coefficient of internal diffusion of moisture in the heat agent.

\section{Conclusion}

The dependence of this coefficient on the temperature of thermal agent is established. The results of theoretical and experimental researches are the basis for development of filtration drying technology of cotton and design sizes of filtration drying of cotton.

\section{References}

[1] V. M. Atamanyuk and Ya. M. Gumnitskiy, NaukovI osnovi fIltratsIynogo sushInnya dispersnih, LvIv: Vidavnitstvo LvIvskoYi polItehnIki, 2013.

[2] V. Atamanyuk, R. HodorIvskiy and M. BasIstiy, "GIdrodinamIka statsIonarnogo sharu granulovanogo," Naukoviy vIsnik NLTU UkraYini: ZbIrnik nauk.-tehn. prats., no. 22.5, pp. 116-121, 2012.

[3] V. M. Atamanyuk, "ZovnIshnIy teplomasoobmIn pIdchas fIltratsIynogo sushInnya", Promyishlennaya teplotehnika, t. 28, \# 5, pp. 47-54, 2006. 